\title{
Periovulatory changes in catfish ovarian oestradiol-17 $\beta$, oestrogen-2-hydroxylase and catechol-O-methyltransferase during GnRH analogue-induced ovulation and in vitro induction of oocyte maturation by catecholoestrogens
}

\author{
B Senthilkumaran and K P Joy \\ Department of Zoology, Banaras Hindu University, Varanasi-221005, India \\ (B Senthilkumaran is now at the National Institute for Basic Biology, Myodaiji, Okazaki 444-8585, Japan) \\ (Requests for offprints should be addressed to $\mathrm{K} P$ Joy)
}

\begin{abstract}
In the catfish Heteropneustes fossilis and Clarias batrachus, ovarian oestrogen-2-hydroxylase (OE-2-H) activity increased significantly at $8 \mathrm{~h}$ after the injection of an ovulatory dose $(0.15 \mu \mathrm{g} / \mathrm{g}$ body weight $)$ of a mammalian GnRH analogue ([D-Ala - Pro $\left.{ }^{9}\right]-$ LHRH ethylamide) and was restored to the $0 \mathrm{~h}$ (control) level after egg-stripping at $16 \mathrm{~h}$. On the other hand, ovarian oestradiol-17 $\beta\left(\mathrm{OE}_{2}\right)$ level and catechol-O-methyltransferase (COMT) activity decreased significantly at $8 \mathrm{~h}$. While the $\mathrm{OE}_{2}$ level was restored to the $0 \mathrm{~h}$ level, COMT activity increased significantly at $16 \mathrm{~h}$. Changes in ovarian $\mathrm{OE}_{2}$ level and enzymes indicate higher synthesis of 2-hydroxylated catecholoestrogens and their degradation during the periovulatory period. Under in vitro conditions, the synthetic catecholoestrogens (CEs, 2- and 4-hydroxylated oestradiol$17 \beta$ and oestrone $\left.\left(\mathrm{OE}_{1}\right)\right)$ induced germinal vesicle break down $(\mathrm{GVBD})$ in a dose- $(0 \cdot 01-10 \mu \mathrm{g} / \mathrm{ml})$ and duration(1-36 h) dependent manner, the mean values of the responses being in the order $2-\mathrm{OH} \mathrm{OE}_{2}>4-\mathrm{OH} \mathrm{OE} \mathrm{OE}_{2}>$
\end{abstract}

2-OH $\mathrm{OE}_{1}>4-\mathrm{OH} \mathrm{OE}_{1}$. The CE-induced GVBD response ( $8 \mathrm{~h}$ induction) was not blocked by prior and subsequent incubations with steroid synthesis inhibitors (cyanoketone, epostane and aminoglutethimide) up to $36 \mathrm{~h}$, suggesting that de novo steroidogenesis is not essential for the response. The percentage of GVBD response to $2-h$ induction by CEs was significantly inhibited by actinomycin D (a transcriptional inhibitor) and cycloheximide (a translational inhibitor), indicating the involvement of both RNA and protein synthesis. The CE-induced 8-h stimulation of GVBD was mildly blocked by propranolol, the $\beta$-adrenergic inhibitor, suggesting the response was partly mediated through a $\beta$-adrenergic receptor mechanism. Incubations with phentolamine, an $\alpha$-adrenergic inhibitor, did not interfere with the CE-induced GVBD response. The results demonstrate CE-related enzymatic changes in teleost (catfish) ovaries and maturation-inducing substance activity of CEs.

Journal of Endocrinology (2001) 168, 239-247

\section{Introduction}

The sequential physiological events of vitellogenesis, oocyte final maturation and ovulation during fish oogenesis are under the differential control of regulatory mechanisms involving principally the pituitary gonadotrophin and ovarian steroid regulators (Chieffi \& Pierantoni 1987, Ho 1987, Nagahama 1987, Yoshikuni \& Nagahama 1991, Kagawa 1994). The vitellogenic phase is initiated and maintained by one of the gonadotrophins (gonadotrophin-I (GTH-I) or follicle-stimulating hormone $(\mathrm{FSH})$ ) in the two gonadotrophin model species (Kawauchi et al. 1989, Yoshikuni \& Nagahama 1991, Swanson \& Dittman 1997) through the mediation of ovarian oestrogens, principally oestradiol-17 $\beta \quad\left(\mathrm{OE}_{2}\right)$. Oocyte maturational and ovulatory events are initiated by the other gonadotrophin (gonadotrophin-II (GTH-II) or luteinizing hormone $(\mathrm{LH})$ ) through the mediation of a maturation-inducing hormone or substance (MIH or MIS), the most common being an ovarian progesterone

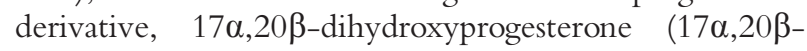
$\mathrm{DP})$ as in many salmonids, cyprinids and silurids, or $17 \alpha, 20 \beta, 21 \beta$-trihydroxyprogesterone $(17 \alpha, 20 \beta, 21 \beta-T P)$ as in sciaenid fish (Goetz 1983, Nagahama 1987, 1994, 1997, Scott \& Canario 1987, Thomas 1994). MIS activity was also demonstrated for corticosteroids (deoxycorticosterone and cortisol) in several teleosts including catfish (Goswami \& Sundararaj 1974, Sundararaj \& Goswami 1977, Goetz 1983, Upadhyaya \& Haider 1986, Rao \& Haider 1992, Haider 1997).

The shift in steroidogenesis from the oestrogenic to progestational phase is indicated by an abrupt decrease in 
mRNA transcripts of aromatase, thus arresting the aromatization of testosterone to $\mathrm{OE}_{2}$ (Nagahama 1994, 1997). However, the fate of $\mathrm{OE}_{2}$ in the blood during the periovulatory period of different teleosts presents varied patterns, including significant decrease, increase, or no changes (see Joy et al. 1998 for references). In H. fossilis, during the periovulatory period plasma $\mathrm{OE}_{2}$ level decreases to the lowest value at $8 \mathrm{~h}$ after gonadotrophinreleasing hormone $(\mathrm{GnRH})$ analogue injection and increases after stripping of eggs at $16 \mathrm{~h}$ (Joy et al. 1998). Since plasma testosterone showed an inverse pattern, we suggested that the $\mathrm{OE}_{2}$ decrease might have been due to inhibited aromatization. Considering the long half-life of $\mathrm{OE}_{2}$ (Querat et al. 1985), a mere inhibition of its biosynthesis may not be adequate to bring such a drastic change in its titre within $8 \mathrm{~h}$. Furthermore, ovarian $\mathrm{OE}_{2}$ level never reaches undetectable/low values, unless the ovary undergoes regression (Singh \& Singh 1987). Therefore, an active mechanism removing the formed oestrogens may be operating as well. This has prompted us to examine the ovarian $\mathrm{OE}_{2}$ catabolism. Since oestrogens $\left(\mathrm{OE}_{2}\right.$ and oestrone, $\left.\mathrm{OE}_{1}\right)$ can be hydroxylated at 2- and 4- carbons of ring $A$ by specific hydroxylases (oestrogen-2/4-hydroxylases), ovaries with high concentrations of the steroid can be potential sites of catecholoestrogen (CE) synthesis (Spicer \& Hammond 1989). The hydroxyoestrogens can be subsequently O-methylated by catechol-O-methyltransferase (COMT) to form methoxyoestrogens (Ball et al. 1983, Fishman 1983). The presence of these enzymes, therefore, indicates CE synthesis and degradation in a given tissue (COMT can be a marker for catecholamine degradation as well).

In the mammalian ovary, the CEs have been demonstrated as potent autocrine/paracrine regulators of ovarian functions. They stimulate progesterone synthesis, cAMP, $\beta$-adrenergic receptors, etc. (Spicer \& Hammond 1989). To our knowledge, there are no studies showing ovarian CE metabolism or function in teleosts. In the first part of the present investigation, evidence for CE metabolism in the catfish ovary is presented. In the second part of the study, the significance of CEs in oocyte final maturation is demonstrated by an in vitro bioassay system for germinal vesicle break down (GVBD) response.

\section{Materials and Methods}

\section{Animals}

Sexually mature gravid female catfish (Heteropneustes fossilis and Clarias batrachus) weighing 90-110 g were collected from local fish markets in Varanasi in the last week of June (late pre-spawning phase) and first week of July (early spawning phase). They were maintained in flow through aquarium under natural photoperiod (average day length $13 \cdot 2 \mathrm{~h}$ ) and ambient temperature (average $28 \pm 2{ }^{\circ} \mathrm{C}$ ) for 2 weeks. The fish were examined for spontaneous ovulation by pressing the abdomen towards the ovipore. They were fed daily with goat liver and allowed to feed ad libitum till a day before experiments were started.

\section{Chemicals}

$\left[\mathrm{D}-\mathrm{Ala}^{6}-\mathrm{Pro}^{9}\right]-\mathrm{LHRH}$ ethylamide, DL-adrenaline, oestradiol-17 $\beta\left(\mathrm{OE}_{2}\right), 2$-hydroxyoestradiol-17 $\beta$ (2-OH $\left.\mathrm{OE}_{2}\right)$, 4-hydroxyoestradiol-17 $\beta$ (4-OH $\left.\quad \mathrm{OE}_{2}\right), \quad 2-$ hydroxyoestrone (2-OH OE ${ }_{1}$ ), 4-hydroxyoestrone (4-OH $\left.\mathrm{OE}_{1}\right)$, reduced nicotinamide adenine dinucleotide (NADPH), propranolol, phentolamine, purified COMT, BSA, cycloheximide, actinomycin D, HEPES buffer and aminoglutethimide were obtained from Sigma (St Louis, MO, USA). $\left[{ }^{14} \mathrm{C}\right] \mathrm{S}$-adenosylmethionine (SAM, specific activity $43 \mathrm{mCi} / \mathrm{mmol}$ ) and $\left[2{ }^{3} \mathrm{H}\right]$ oestradiol- $17 \beta$ (specific activity $22 \cdot 1 \mathrm{Ci} / \mathrm{mmol}$ ) were purchased from NEN (Boston, MA, USA) and Amersham (Buckinghamshire, UK) respectively. Cyanoketone and epostane were gifts of Sterling-Winthrop Research Institute, New York to Dr S Haider, Department of Zoology, Banaras Hindu University. All other chemicals were of analytical grade and purchased locally.

Dynamics of ovarian oestrogen-2-hydroxylase (OE-2-H) and COMT during periovulatory period

Induction of ovulation Thirty females each of $H$. fossilis and C. batrachus were divided into two groups of 15 each. Group 1 was injected with $0 \cdot 15 \mu \mathrm{g} / \mathrm{g}$ body weight of a mammalian GnRH analogue in the evening (1800 h). Group II fish were injected with an equal volume of the vehicle $(0 \cdot 7 \% \mathrm{NaCl}+0 \cdot 25 \% \mathrm{BSA}$, fraction $\mathrm{V})$. Five fish each from the two groups were sacrificed by decapitation at 0,8 and $16 \mathrm{~h}$ after the injections. At $16 \mathrm{~h}$, the fish were checked for ovulation by hand stripping before sacrificing.

Enzyme assays The ovaries were removed carefully, placed on ice, weighed (including the stripped eggs) and stored briefly (1-2 days) at $-20{ }^{\circ} \mathrm{C}$ prior to the assay of enzymes and total protein. The ovaries of all the samples were freeze-thawed only once to avoid loss of enzyme activity.

Assay of COMT COMT activity in the ovarian tissue extract (aliquots from $50 \mathrm{mg}$ of ovarian tissue/ml $0.6 \%$ $\mathrm{KCl}$ solution) was assayed by the radioisotopic method of Parvez \& Parvez (1973) as described by Joy \& Senthilkumaran (1998). DL-adrenaline and $\left[{ }^{14} \mathrm{C}\right] \mathrm{SAM}$ were used as substrates and co-substrates respectively. Radioactivity of ${ }^{14} \mathrm{C}$-methylated product was counted in a Beckman LS-1801 liquid scintillation counter. The assay was validated using increasing concentrations of the ovarian tissue extract and purified COMT. The resulting plot showed both parallelism and linearity up to $15 \mathrm{mg}$ of ovarian tissue and 500 units of COMT. 
Assay of OE-2-H The enzyme was assayed by the radioisometric method of Numazawa et al. (1980). The ovaries were homogenized gently on ice in HEPES buffer $(0 \cdot 1 \mathrm{M}$, $\mathrm{pH} 7 \cdot 4 ; 25 \mathrm{mg}$ of ovarian tissue/ml buffer) using a micropestle and an Eppendorf tube. The supernatant $(40 \mu \mathrm{l}(1 \mathrm{mg}$ tissue $))$ was incubated with $\left[2-{ }^{3} \mathrm{H}\right] \mathrm{OE}_{2}$ $(0.4 \mu \mathrm{Ci}$ in $0.4 \mu \mathrm{l}$ ) dissolved in propylene glycol (final concentration, $5 \% \mathrm{v} / \mathrm{v})$, NADPH $(2 \mathrm{mM}$ as a co-factor $)$ and HEPES buffer $(0 \cdot 1 \mathrm{M}, \mathrm{pH} 7 \cdot 4)$. The final volume of incubation medium was $50 \mu \mathrm{l}$. The incubation was conducted at $26{ }^{\circ} \mathrm{C}$ in an Eppendorf tube immersed in a continuous shaking water bath incubator for an hour. The tubes were placed on ice for $5 \mathrm{~min}$ to stop the reaction. The volume of the reaction mixture was made up to $1 \mathrm{ml}$ by adding HEPES buffer. The mixture was then extracted with $4 \mathrm{ml}$ dichloromethane to remove any non-converted $\left[2-{ }^{3} \mathrm{H}\right] \mathrm{OE}_{2}$ with a prior addition of $40 \mu \mathrm{g} \mathrm{OE}_{2}$ (dissolved in propylene glycol, $5 \% \mathrm{v} / \mathrm{v}$ as the carrier). Radioactivity of the tritium label $\left({ }^{3} \mathrm{H}_{2} \mathrm{O}\right)$ released into the aqueous fraction was counted in a Beckman LS 1801 counter. Corrections for non-enzymatically released tritium label were made using the radioactivity of ${ }^{3} \mathrm{H}$ in control samples (pre-heated tissue extracts $\left(10-15 \mathrm{~min}\right.$ heating at $\left.100{ }^{\circ} \mathrm{C}\right)$ ). The assay was validated with increasing concentrations of ovarian tissue extract. The resulting plot showed both parallelism and linearity up to $25 \mathrm{mg}$ of ovarian tissue.

\section{RIA of oestradiol-17 $\beta\left(\mathrm{OE}_{2}\right)$}

Ovarian extracts from both control and $\mathrm{GnRH}$ analogue treated fish were analysed for $\mathrm{OE}_{2}$ level, using the RIA protocol described previously (Senthilkumaran \& Joy 1994).

\section{Total protein assay}

The total protein content in the ovarian extract was assayed by the method of Lowry et al. (1951) using BSA as standard.

\section{In vitro bioassay of $G V B D$}

Oocyte incubation The incubation medium was prepared by dissolving $3.74 \mathrm{~g} \mathrm{NaCl}, 0.32 \mathrm{~g} \mathrm{KCl}, 0.16 \mathrm{~g}$ $\mathrm{CaCl}_{2}, 0.1 \mathrm{~g} \mathrm{NaH}_{2} \mathrm{PO}_{4} \cdot 2 \mathrm{H}_{2} \mathrm{O}, 0.16 \mathrm{~g} \mathrm{MgSO}_{4} .7 \mathrm{H}_{2} \mathrm{O}$, $0.8 \mathrm{~g}$ glucose and $0.008 \mathrm{~g}$ phenol red in 1 litre of tripledistilled water and sterilized (Upadhaya \& Haider 1986). The $\mathrm{pH}$ was adjusted to $7 \cdot 5$ with $1 \mathrm{M}$ sterilized sodium bicarbonate solution. Penicillin (200 $000 \mathrm{U})$ and streptomycin sulphate $(200 \mathrm{mg})$ were added and stored at $4{ }^{\circ} \mathrm{C}$. The ovaries were dissected out under aseptic conditions, cut into small pieces and washed three times with the incubation medium. Full grown, folliculated postvitellogenic oocytes (henceforth referred to as oocytes) with centrally located germinal vesicles $(\mathrm{GV})$ were only selected for incubations. The incubations were set up in triplicate for each test in small Petri dishes containing 35-40 oocytes in $3 \mathrm{ml}$ of incubation medium at $21 \pm 2{ }^{\circ} \mathrm{C}$. After $36 \mathrm{~h}$ of incubation, the oocytes were treated with a clearing solution consisting of $5 \%$ formalin and $4 \%$ acetic acid to check GVBD and were scored individually. The percentage of GVBD was calculated from the ratio of the number of oocytes that had undergone GVBD to the total number of oocytes incubated.

Experiments Effects of different concentrations of CEs on GVBD Thirty-five to 40 oocytes from $H$. fossilis and C. batrachus were incubated in triplicate in $3 \mathrm{ml}$ of incubation medium (control) or the medium containing 0.01, 0.05, $0 \cdot 10,0 \cdot 50,1 \cdot 0,2 \cdot 0,5 \cdot 0$ and $10 \cdot 0 \mu \mathrm{g} / \mathrm{ml}$ of $2-\mathrm{OH} \mathrm{OE}$, $4-\mathrm{OH} \mathrm{OE}, 2-\mathrm{OH} \mathrm{OE}$ and 4-OH $\mathrm{OE}_{1}$. The CEs were dissolved in 50-100 $\mu \mathrm{l}$ ethanol and diluted with the incubation medium. In the control incubations, the medium contained an equal volume of ethanol. After $36 \mathrm{~h}$, GVBD was scored in all groups. This experiment was repeated with oocytes from three donor fish in the same spawning season and in two consecutive years (data not shown).

Time course effects of CE stimulation of GVBD Thirty-five to 40 oocytes of $H$. fossilis and C. batrachus were incubated in triplicate in $3 \mathrm{ml}$ of incubation medium containing $1.0 \mu \mathrm{g} / \mathrm{ml}$ of $2-\mathrm{OH} \mathrm{OE} 2,4-\mathrm{OH} \mathrm{OE} \mathrm{OE}_{2}, 2-\mathrm{OH} \mathrm{OE} \mathrm{OE}_{1}$ and 4-OH $\mathrm{OE}_{1}$ each (dissolved in 50-100 $\mu$ l of ethanol) for various duration $(1,2,4,6,8,12,18,24$ and $36 \mathrm{~h})$. After the end of each pulse interval, the oocytes were transferred to fresh medium without CEs to complete the $36 \mathrm{~h}$ interval (except the $36 \mathrm{~h}$ group) and GVBD was scored for each group. In the control, oocytes were incubated in the medium containing the same amount of ethanol for $36 \mathrm{~h}$, following which GVBD was scored. This experiment was repeated using oocytes from three donor fish in the same spawning season and in two consecutive years (data not shown).

Effects of steroid synthesis inhibitors (cyanoketone, epostane and aminoglutethimide) on CE-stimulated GVBD Thirty-five to 40 oocytes from five $H$. fossilis and C. batrachus each were pre-incubated in triplicate with medium containing $10 \mu \mathrm{g} / \mathrm{ml}$ of cyanoketone, epostane or aminoglutathamide for $2 \mathrm{~h}$, followed by incubation with $1.0 \mu \mathrm{g} / \mathrm{ml}$ each of different CEs in $3 \mathrm{ml}$ of medium for $8 \mathrm{~h}$. The oocytes were then transferred again to the medium containing each of cyanoketone $(10.0 \mu \mathrm{g} / \mathrm{ml})$, epostane $(10.0 \mu \mathrm{g} / \mathrm{ml})$ or aminoglutethimide $(10 \cdot 0 \mu \mathrm{g} / \mathrm{ml})$ for the remaining $26 \mathrm{~h}$. The inhibitors were dissolved in 50-100 $\mu \mathrm{l}$ ethanol. For controls, oocytes were incubated with each of the steroid synthesis inhibitors or in medium containing equal amounts of ethanol (negative control). A positive control incubation with each CE was run concurrently to monitor the GVBD response. An $8 \mathrm{~h}$ stimulation of oocytes was chosen to test the effects of the steroid synthesis inhibitors, 
as studies by other workers employed $6-8 \mathrm{~h}$ stimulation times to test de novo steroidogenic involvement during GVBD bioassay. Furthermore, our pilot studies of preincubating oocytes with the inhibitors followed by 2 or $6 \mathrm{~h}$ CE stimulation of oocytes and again treated with the inhibitors treatment produced more or less a similar response (data not shown) as observed for $8 \mathrm{~h}$ CEstimulated oocytes. GVBD was scored at the end of $36 \mathrm{~h}$.

Effects of actinomycin $D$ (a transcriptional inhibitor) and cycloheximide (a translational inhibitor) on CE-induced GVBD response About 35-40 oocytes of both catfish species (five donors) were pre-incubated in triplicate with $10.0 \mu \mathrm{g} / \mathrm{ml}$ of actinomycin $\mathrm{D}$ or cycloheximide for $2 \mathrm{~h}$, followed by $1.0 \mu \mathrm{g} / \mathrm{ml}$ of each CE for $2 \mathrm{~h}$, and then treated again with actinomycin D $(10 \cdot 0 \mu \mathrm{g} / \mathrm{ml})$ or cycloheximide $(10 \cdot 0 \mu \mathrm{g} /$ $\mathrm{ml}$ ) for the next $2 \mathrm{~h}$. The oocytes were then transferred to the plain medium and incubated for the remaining $30 \mathrm{~h}$. A minimum of $2 \mathrm{~h}$ stimulation time by CEs was chosen to show transcriptional or translational involvement during oocyte maturation. For controls, oocytes were incubated in the medium only (negative control), medium containing the inhibitors or medium containing CE (2 h stimulation), followed by the medium only (positive control). GVBD response was scored after $36 \mathrm{~h}$ in all cases. The inhibitors were directly dissolved in the incubation medium.

Effects of $\alpha$ - and $\beta$-adrenergic inhibitors on CE-stimulated GVBD About 35-40 oocytes of both catfish species (five donors) were pre-incubated in triplicate in the medium containing $10 \cdot 0 \mu \mathrm{g} / \mathrm{ml}$ of propranolol, a $\beta$-adrenergic inhibitor, or phentolamine, an $\alpha$-adrenergic inhibitor, for $2 \mathrm{~h}$ followed by incubation with $1 \mu \mathrm{g} / \mathrm{ml}$ of CEs for $8 \mathrm{~h}$. Subsequently, the oocytes were transferred again to the medium containing $10 \cdot 0 \mu \mathrm{g} / \mathrm{ml}$ of propranolol or phentolamine for the remaining $26 \mathrm{~h}$. For control, oocytes were incubated with CEs for $8 \mathrm{~h}$ followed by the medium only, or in medium containing the drugs only (positive control), or in the medium alone (negative control). After $36 \mathrm{~h}$ GVBD was recorded in all cases. The drugs were dissolved in the medium.

\section{Statistical analysis}

Data were expressed as means \pm S.E.M.s. Statistical significance between control and treated (GnRH analogue and various inhibitors) groups was tested by Student's multiple $t$-test. The data of concentration-response and time course studies were analysed by one-way ANOVA, followed by Newman-Keuls' multiple comparison test.

\section{Results}

Periovulatory changes in ovarian OE-2-H, COMT and $O E_{2}$ level

The administration of $0.15 \mu \mathrm{g}$ of GnRH analogue per gram body weight of fish induced ovulation in both catfish
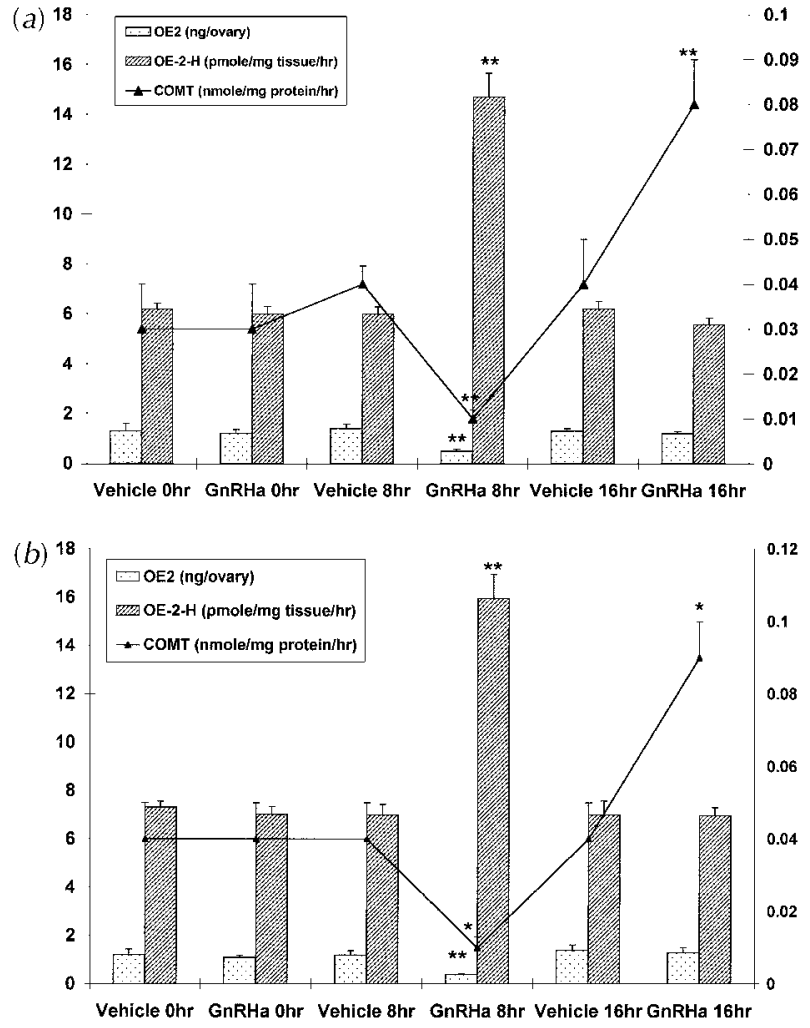

Figure 1 Effects of a mammalian $\mathrm{GnRH}$ analogue on ovarian $\mathrm{OE}_{2}$ level and OE-2-H activity (left vertical axis) and COMT activity (right vertical axis) in $H$. fossilis (a) and C. battachus (b). Values are means \pm S.E.M.S. ${ }^{*} P<0 \cdot 01,{ }^{*} P<0 \cdot 001$, Student's multiple $t$-test.

species. Eggs could be stripped out at $16 \mathrm{~h}$ after the injection. The fish that received the vehicle did not ovulate upon stripping. In the non-ovulated fish (vehicle control groups), the ovarian activity of $\mathrm{OE}-2-\mathrm{H}$ and COMT did not vary significantly at any of the intervals (Fig. 1a,b). In the GnRH analogue groups, OE-2-H activity increased significantly at $8 \mathrm{~h}$ in both species $(P<0 \cdot 001$, Student's $t$-test). At $16 \mathrm{~h}$, after egg stripping, the enzyme activity was restored to the control levels. In contrast, COMT activity decreased significantly at $8 \mathrm{~h}(H$. fossilis, $P<0.001$ and C. batrachus, $P<0 \cdot 01)$ and increased sharply at $16 \mathrm{~h}$. After $\mathrm{GnRH}$ analogue treatment, ovarian $\mathrm{OE}_{2}$ level decreased significantly $(P<0 \cdot 001)$ at $8 \mathrm{~h}$ when compared with vehicle control. After egg stripping at $16 \mathrm{~h}$, the $\mathrm{OE}_{2}$ level was restored to the control range. The activity of enzymes and $\mathrm{OE}_{2}$ level did not change at $0 \mathrm{~h}$.

\section{In vitro oocyte $G V B D$ response}

Effects of different concentrations of CEs In both $H$. fossilis and C. batrachus, the incubation of oocytes with different concentrations of CEs $(0 \cdot 01-10 \mu \mathrm{g} / \mathrm{ml})$ produced overall significant differences on the percentage of GVBD 

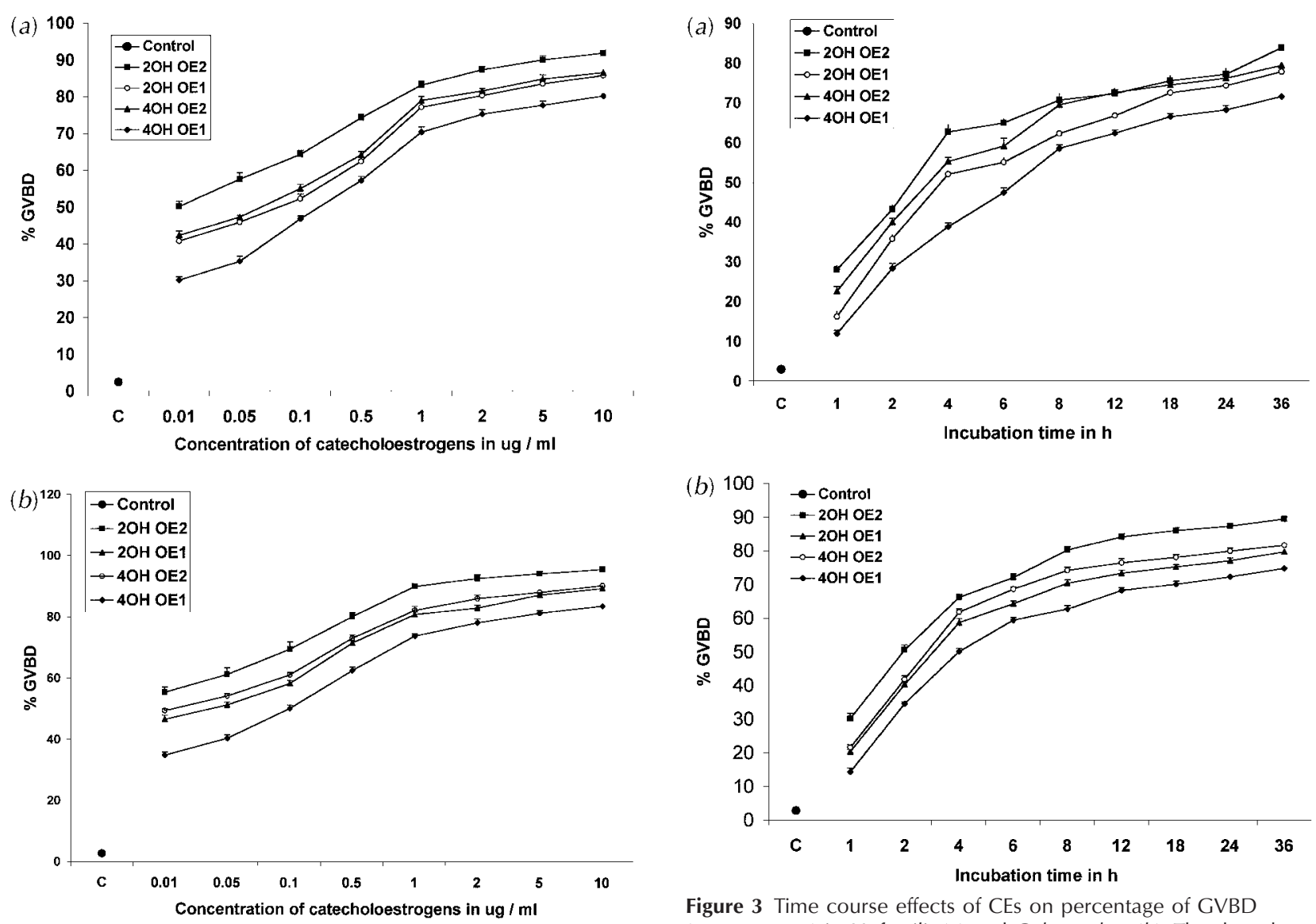

Figure 3 Time course effects of CEs on percentage of GVBD (mean \pm S.E.M.) in H. fossilis (a) and C. batrachus (b). The data show overall significant increases $(P<0 \cdot 001$, one-way ANOVA; $F$-values for $2 \mathrm{OH} \mathrm{OE}_{2}, 2 \mathrm{OH} \mathrm{OE}, 4 \mathrm{OH} \mathrm{OE}$ and $4 \mathrm{OH} \mathrm{OE}_{1}$ groups are $160 \cdot 2,127 \cdot 9,138.7$ and $110 \cdot 4$ in $\mathrm{H}$. fossilis, and 200.0, 162.7, $187 \cdot 2$ and $160 \cdot 3$ in C. batrachus respectively). The values of all CE-treated groups are significantly higher $(P<0 \cdot 05$,

Newman-Keuls' test) than control group values. C, control.

response (Fig. $2 a, b ; P<0 \cdot 001$, one-way ANOVA). The CE-induced GVBD response was significant at all concentrations $(P<0 \cdot 05$, Newman-Keuls' test) compared with the control values. A comparison of the mean values of the percentage GVBD response of different CEs at the lowest $(0 \cdot 01 \mu \mathrm{g} / \mathrm{ml})$ and highest $(10 \mu \mathrm{g} / \mathrm{ml})$ concentrations shows that $2-\mathrm{OH} \mathrm{OE}$ is the most, and $4-\mathrm{OH} \mathrm{OE}$ the least effective in both species (Student's multiple $t$-test). The percentage of GVBD is 55 and $96 \%$ for C. batrachus and 50 and $92 \%$ for $H$. fossilis at the respective concentrations of $2-\mathrm{OH} \mathrm{OE} 2$. The responses for $4-\mathrm{OH} \mathrm{OE}$ are 35 and $84 \%$ for C. batrachus and 30 and $80 \%$ for $H$. fossilis respectively. The GVBD response in $4-\mathrm{OH} \mathrm{OE}_{2}$ and $2-\mathrm{OH} \mathrm{OE}$ groups is almost in the same range at different concentrations.

Time course effects of CEs on GVBD The incubation of oocytes with $1 \mu \mathrm{g} / \mathrm{ml}$ concentration of CEs produced overall significant increases in the percentage of GVBD in both species (Fig. $3 a, b ; P<0 \cdot 001$, one-way ANOVA). The percentage of GVBD increased significantly at all intervals $(P<0 \cdot 05$, Newman-Keuls' test). The highest response was in the $2-\mathrm{OH} \mathrm{OE} \mathrm{E}_{2}$ groups and the lowest in the $4-\mathrm{OH} \mathrm{OE}$ groups.

Effects of steroid synthesis inhibitors on CEstimulated GVBD The incubation of catfish oocytes with cyanoketone, epostane or aminoglutethimide (10 $\mu \mathrm{g} /$ $\mathrm{ml}$ ) for $2 \mathrm{~h}$, followed by stimulation with $1 \mu \mathrm{g} / \mathrm{ml}$ of various CEs for $8 \mathrm{~h}$, and subsequent incubation with the inhibitors $(10 \mu \mathrm{g} / \mathrm{ml})$ up to a total of $36 \mathrm{~h}$ did not inhibit the GVBD response due to the CEs (Fig. 4; $P<0 \cdot 001$, Student's multiple $t$-test). The inhibitors alone did not 


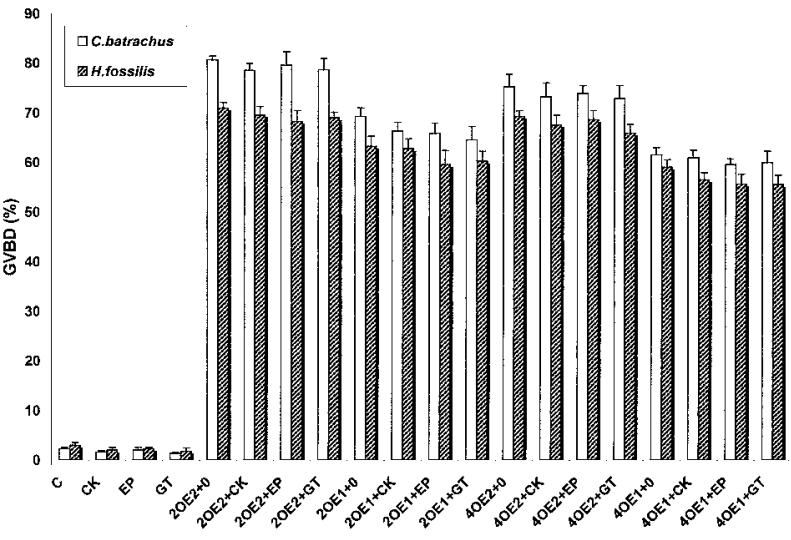

Figure 4 Effects of the steroid-synthesizing inhibitors, cyanoketone (CK), epostane (EP) and aminoglutethimide (GT) on CEs $\left(2 \mathrm{OE}_{2}\right.$ and $2 \mathrm{OE}_{1}$, and $4 \mathrm{OE}_{2}$ and $4 \mathrm{OE}_{1}$ ) on GVBD in $H$. fossilis and $\mathrm{C}$. batrachus (mean \pm S.E.M.). C, control. The inhibitors did not significantly affect the GVBD responses in the CE-treated groups (Student's multiple $t$-test).

elicit any significant response compared with the control groups.

Effects of actinomycin $D$ and cycloheximide on CE-induced GVBD The incubation of catfish oocytes first with actinomycin D or cycloheximide for $2 \mathrm{~h}$, followed by various CEs $(1 \mu \mathrm{g} / \mathrm{ml})$ for $2 \mathrm{~h}$ and then again with actinomycin $\mathrm{D}$ or cycloheximide for the next $2 \mathrm{~h}$, and finally in plain medium up to a total of $36 \mathrm{~h}$ significantly inhibited GVBD response in comparison with the respective CE groups (Fig. 5; $P<0 \cdot 001$, Student's multiple $t$-test). The inhibition was greater in the actinomycin D (C. batrachus, 66-72\%; H. fossilis, 60-65\%) than

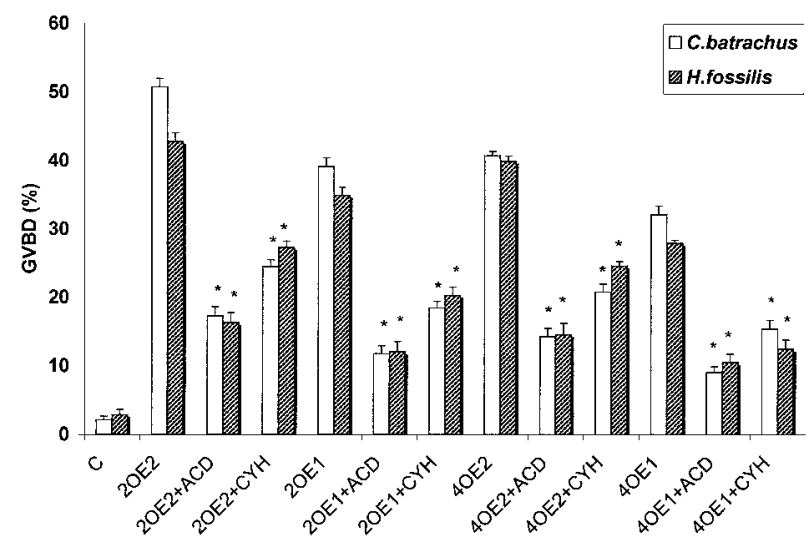

Figure 5 Effects of transcriptional inhibitor, actinomycin D (ACD) and translational inhibitor, cycloheximide $(\mathrm{CYH})$ on $\mathrm{CE}$-induced GVBD in H. fossilis and C. batrachus (mean \pm S.E.M.). C, control. The GVBD response was significantly inhibited compared with respective control groups $\left({ }^{\star} P<0 \cdot 001\right.$, Student's multiple $t$-test).

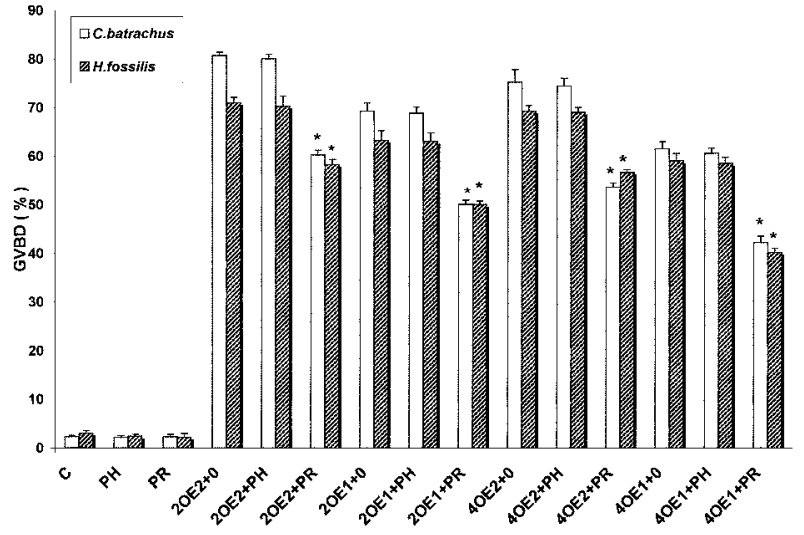

Figure 6 Effects of $\alpha$-adrenergic inhibitor, phentolamine $(\mathrm{PH})$ and $\beta$-adrenergic inhibitor, propranolol (PR) on CE-induced GVBD in H. fossilis and C. batrachus (mean \pm S.E.M.). Only the $\beta$-adrenergic inhibitor decreased GVBD response significantly $\left({ }^{*} P<0 \cdot 001\right.$, Student's multiple $t$-test).

cycloheximide (C. batrachus, 49-53\%; H. fossilis, 36-55\%) groups. The inhibitors alone did not induce any significant effect.

Effects of phentolamine and propranolol on CEinduced GVBD The incubation of catfish oocytes with $10 \mu \mathrm{g} / \mathrm{ml}$ of phentolamine, an $\alpha$-adrenergic inhibitor for $2 \mathrm{~h}$, followed by stimulation with various CEs $(1 \mu \mathrm{g} / \mathrm{ml})$ for $8 \mathrm{~h}$, and then incubated again with $10 \mu \mathrm{g} / \mathrm{ml}$ of phentolamine for $26 \mathrm{~h}$ did not inhibit the CE-induced GVBD response (Fig. 6). However, incubation of the oocytes with propranolol $(10 \mu \mathrm{g} / \mathrm{ml}, \quad$ a $\beta$-adrenergic blocker) under similar incubation conditions inhibited significantly the GVBD response: C. batrachus, 25-31\%, H. fossilis, 18-32\% (P<0.001, Student's multiple $t$-test). The inhibitors alone did not produce any significant effect.

\section{Discussion}

This study presents evidence for dynamics of $\mathrm{OE}_{2}$ and CE-related enzymes in teleost (catfish) ovaries during $\mathrm{GnRH}$ analogue-induced ovulation. In a previous study with similar experimental approach, we reported periovulatory changes in plasma levels of GTH-II, OE testosterone, progesterone and cortisol after $\mathrm{GnRH}$ analogue treatment that led to ovulation in the catfish $H$. fossilis (Joy et al. 1998). The peak rise of ovarian OE-2-H coincided with the GTH-II and testosterone peak rises, and $\mathrm{OE}_{2}$ decline at $8 \mathrm{~h}$ after the injection. This indicates that GTH-II seems to stimulate the enzyme activity as has been reported by Chakraborty et al. (1988) in rat ovary which resulted in decreased $\mathrm{OE}_{2}$ level. OE-2-H activity is also stimulated by testosterone (Poth et al. 1983, Li et al. 1986, Quail \& Jellinck 1987). The rise in plasma 
testosterone level reported by us (Joy et al. 1998) may suggest a similar rise of the steroid in the ovary and the high ovarian testosterone concentration may facilitate $\mathrm{OE}-2-\mathrm{H}$ activity in the catfish. After stripping the ovulated eggs (16 $\mathrm{h}$ after the injection), $\mathrm{OE}-2-\mathrm{H}$ returned to the $0 \mathrm{~h}$ level to coincide with the fall in plasma GTH-II and testosterone (Joy et al. 1998), and the rise in both plasma and ovarian $\mathrm{OE}_{2}$. In contrast, ovarian COMT decreased significantly at $8 \mathrm{~h}$ and increased sharply after egg stripping at $16 \mathrm{~h}$, suggesting methylation of CEs. Since CEs have a short half-life ( $1 \mathrm{~h}$ for $2-\mathrm{OH} \mathrm{OE}{ }_{2}$, see Spicer \& Hammond 1989), the decrease in endogenous COMT activity at $8 \mathrm{~h}$ is an endogenous mechanism to prolong the half-life of CEs (Spicer et al. 1987) for physiological activity during the periovulatory period $(8 \mathrm{~h})$. This interval coincides with the oocyte maturational process since eggs can be stripped from this time onwards. The high activity of COMT at $16 \mathrm{~h}$ suggests degradation of CEs, a terminal inactivation step (Ball et al. 1983, Fishman 1983). The regulation of ovarian COMT activity is not clearly understood. In rats, ovarian COMT activity is significantly lower during oestrus (ovulation) than during dioestrus. COMT activity is increased after progesterone plus $\mathrm{OE}_{2}$ treatment in rabbit uterus (Spicer \& Hammond 1989). In the catfish ovary, increased level of COMT was found coinciding with the rise in $\mathrm{OE}_{2}$ level at $16 \mathrm{~h}$, suggesting $\mathrm{OE}_{2}$ modulation of COMT activity. In the catfish, ovariectomy and/or $\mathrm{OE}_{2}$ replacement modulate hypothalamic COMT activity (Joy \& Senthilkumaran 1998). The patterns of periovulatory changes in $\mathrm{OE}_{2}$ and $\mathrm{CE}$-related enzymes strongly indicate enhanced $\mathrm{OE}_{2}$ catabolism towards CE formation and degradation in the catfish ovary. Since oestrogens have little or even an inhibitory role on oocyte final (meiotic) maturation in teleosts including the catfish (Sundararaj \& Goswami 1977, Nagahama 1987), their removal by converting into CE may be an important physiological step during the periovulatory period. A direct demonstration of CEs and their metabolites remains. Since CEs have very short half-lives and are very labile (Spicer \& Hammond 1989), measurement of CEs requires sensitive HPLC with electrochemical detector system, at present a constraint for us.

The physiological significance of CEs in ovarian function is not known in teleosts. In mammals, CEs have been demonstrated to be paracrine/autocrine regulators of ovarian physiology (Hudson et al. 1987, Spicer \& Hammond 1989, Tekpetey \& Armstrong 1994). The pattern of enzyme changes during the periovulatory period prompted us to study the direct effect, if any, of synthetic CEs on catfish oocyte final (meiotic) maturation. The results show that all the CEs tested induced GVBD and that this could be positively correlated with both CE concentration and incubation time. To our knowledge, this is the first report on CEs eliciting a MIS-like response in any teleost species or vertebrate. Out of the four CEs tested, 2- $\mathrm{OH} \mathrm{OE}_{2}$ appears to be more effective than others in inducing GVBD, judging from the mean percentage of GVBD at the lowest and highest concentrations tested. The C. batrachus oocytes showed a higher response than the $H$. fossilis oocytes. The MIS property of the CEs seems to be associated with the hydroxylations at 2- or 4- position of the ring $\mathrm{A}$, as their parent steroids exhibit only negligible MIS activity in catfish (Sundararaj \& Goswami 1977, Upadhyaya \& Haider 1986, Rao \& Haider 1992). The structure-activity relationship needs to be examined in detail in future studies.

Since it is well known that ovarian CEs are potent stimulators of progesterone synthesis (Spicer \& Hammond 1989, Tekpetey \& Armstrong 1994), we examined whether de novo steroidogenesis is essential for the CEinduced GVBD response. When the oocytes were pre-incubated with cyanoketone and epostane (inhibitors of $3 \beta$-hydroxysteroid dehydrogenase, $3 \beta-\mathrm{HSD}$ ), and aminoglutethimide (a P450 antagonist) for $2 \mathrm{~h}$, and then stimulated with different CEs for $8 \mathrm{~h}$, and subsequently incubated again with steroidogenic inhibitors, the GVBD response was not affected, indicating that it was independent of de novo steroidogenesis by ovarian follicles. It has been demonstrated that the $3 \beta-H S D$ blockers cyanoketone and epostane do not block progesterone- or $17 \alpha, 20 \beta-D P-i n d u c e d$ oocyte maturation but block gonadotrophin/pituitary extract-induced maturation in teleosts, including catfish (Nagahama 1987, 1994, 1997, Rao \& Haider 1992). In the present study, we also used the P450 antagonist, aminoglutethimide, that has a broad action at several steroid conversion steps and obtained similar results. These results show that, like $17 \alpha, 20 \beta-D P$, CEs stimulate oocytes directly to initiate maturational process.

The CE-induced GVBD response was inhibited to varying degrees by actinomycin D (a transcriptional inhibitor) and cycloheximide (a translational inhibitor) indicating simultaneous RNA and protein synthesis during the maturation of the oocytes. The pattern of the inhibitory response, however, showed differences with regard to the inhibitors, CEs and species. GVBD response was more significantly inhibited by actinomycin D (C. batrachus: 66-72\%, H. fossilis: 60-65\%) than cycloheximide (C. batrachus: $49-53 \%, H$. fossilis: $36-55 \%)$. The strong inhibitory response of actinomycin D on CE-induced GVBD response is similar to that observed in gonadotrophininduced GVBD but different from other steroid- (e.g. deoxycorticosterone, $17 \alpha, 20 \beta-\mathrm{DP})$ and insulin-like growth factor-I-induced oocyte maturation (Sundararaj \& Goswami 1977, Goetz 1983, Nagahama 1987, 1994, Jalabert et al. 1991, Kagawa et al. 1994). In the latter case, only translational activity (protein synthesis) was involved during the GVBD response. While the significance of translational inhibition by cycloheximide has been related to the synthesis of oocyte cytoplasmic maturation promoting factors (MPF) (Nagahama 1990, 1997 Kagawa et al. 1994), that of transcriptional inhibition is not clear. It may 
be related to the MIH production as in the case of gonadotrophin-induced oocyte maturation (Nagahama 1990, 1997; Kagawa et al. 1994) or to the synthesis of MPF itself. The involvement of transcriptional activity during the CE-induced GVBD response suggests that the CEs may interact with nuclear receptors, similar to the parent oestrogens, as reported in mammals (MacLusky et al. 1983, Spicer \& Hammond 1989).

Because of the catechol structure of the ring A, the CEs can bind to catecholamine (adrenergic) receptors on the cell surface (Paden et al. 1983, Spicer \& Hammond 1989). In the present study, propranolol, the $\beta$-adrenoceptor antagonist, could significantly inhibit the CE-induced GVBD response but phentolamine, an $\alpha$-adrenoceptor antagonist, did not. This indicates that CEs may act on $\beta$-adrenergic receptors on the oocyte membrane to mediate GVBD response. This fact is also strengthened by the results of a preliminary study (our unpublished data) that noradrenaline $(1 \mu \mathrm{g} / \mathrm{ml}$ for $6 \mathrm{~h})$, but not dopamine and adrenaline, induced GVBD in $H$. fossilis $(44 \cdot 0 \pm 1 \cdot 25 \%)$ and $C$. batrachus $(40 \cdot 7 \pm 1 \cdot 32 \%)$. Considering the bifunctional potentials of the CEs, they may employ both mechanisms (steroid and adrenergic receptors), the elucidation of which remains.

Since folliculated oocytes (oocytes surrounded by a single granulose cell layer, basement membrane and thecal cells) were used in the incubations, the GVBD agonists might have acted through the follicle cells or gained direct access on oolemma through gap junctions (between granulose cells or between granulose cell and oolemma). $\mathrm{OE}-2-\mathrm{H}$ activity and CE synthesis occur mainly in the granulosa in mammalian ovarian follicles (Spicer \& Hammond 1989). This may be true for fish ovary too, in which case CEs can act directly on oolemma to effect GVBD response. These aspects are to be investigated in further studies.

In conclusion, the pattern of changes in ovarian $\mathrm{OE}_{2}$, $\mathrm{OE}-2-\mathrm{H}$ and COMT points to stimulation of CE synthesis and degradation during GnRH-induced ovulation. Synthetic CEs induced GVBD that is concentration- and duration-dependent. The GVBD response is independent of de novo steroidogenesis and involves both transcriptional and translational processes. The CEs may engage both oestrogen and $\beta$-adrenergic receptors during the GVBD response.

\section{Acknowledgements}

This work was partly supported by a research grant of the CSIR, New Delhi, India to K P J We are grateful to Dr S Haider for his cooperation and providing cyanoketone and epostane which were given to him by Sterling-Winthrop Research Institute, New York, USA, and to Dr S K Chaube and Dr I Chowdhury for various help during the investigation.

\section{References}

Ball P, Haupt M \& Knuppen R 1983 Biogenesis and metabolism of catechol estrogens in vitro. In Catechol Estrogens, pp 91-103. Eds GR Merriam \& MB Lipsett. New York: Raven.

Chakraborty C, Sen M \& Johnson DC 1988 The estrogen-2 hydroxylase activity of the gonadotropin-stimulated hypophysectomized immature rat ovary. Proceedings of the Society for Experimental Biology and Medicine 189 189-195.

Chieffi G \& Pierantoni R 1987 Regulation of ovarian steroidogenesis. In Hormones and Reproduction in Fishes, Amphibians, and Reptiles, pp 117-144. Eds DO Norris \& R E Jones. New York: Plenum.

Fishman J 1983 Aromatic hydroxylation of estrogens. Annual Review of Physiology 45 61-72.

Goetz FM 1983 Hormonal control of oocyte final maturation and ovulation in fishes. In Fish Physiology, Vol IX B, pp 117-170. Eds WS Hoar, DJ Randall \& EM Donaldson. New York: Academic Press.

Goswami SV \& Sundararaj BI 1974 Effects of $\mathrm{C}_{18}, \mathrm{C}_{19}$, and $\mathrm{C}_{21}$ steroids on in vitro maturation of oocytes of the catfish, Heteropneustes fossilis (Bloch). General and Comparative Endocrinology $23282-285$.

Haider S 1997 Hormonal control of oocyte maturation in fish. In Advances in Fish Research, vol 2, pp 285-298. Ed BR Singh. Delhi: Narendra Publishing House.

Hudson KE, Wickings EJ \& Hillier SG 1987 Effects of 2-hydroxyoestradiol, oestradiol and testosterone on FSH-induction of catecholamine- and gonadotropin-responsive progesterone biosynthesis in rat granulosa cell cultures. Journal of Steroid Biochemistry 28 267-272.

Ho S 1987 Endocrinology of vitellogenesis In Hormones and Reproduction in Fishes, Amphibians, and Reptiles, pp 145-169. Eds DO Norris \& RE Jones. New York: Plenum.

Jalabert B, Fosteir A, Breton B \& Weil C 1991 Oocyte maturation in vertebrates. In Vertebrate Endocrinology: Fundamentals and Biomedical Implications, vol 4, part A - Reproduction, pp 23-90. Eds PKT Pang \& MP Schreibman. New York: Academic Press.

Joy KP \& Senthilkumaran B 1998 Annual and diurnal variations in, and effects of altered photoperiod and temperature, ovariectomy, and estradiol-17 $\beta$ replacement on catechol-o-methyltransferase level in brain regions of catfish, Heteropneustes fossilis. Comparative Biochemistry and Physiology 119C 37-44.

Joy KP, Senthilkumaran B \& Sudhakumari CC 1998 Periovulatory changes in hypothalamic and pituitary monoamines following GnRH analogue treatment in the catfish Heteropneustes fossilis: a study correlating changes in plasma hormone profiles. Journal of Endocrinology 156 365-372.

Kagawa H 1994 Oogenesis. In Biochemistry and Molecular Biology of Fishes, vol 3, pp 292-304. Eds PW Hochachka \& TP Mommsen. Amsterdam: Elsevier.

Kagawa H, Kobayashi M, Hasegawa Y \& Aida K 1994 Insulin and insulin-like growth factor I and II induce final maturation of oocytes of red seabream, Pagarus major, in vitro. General and Comparative Endocrinology 95 293-300.

Kawauchi H, Suzuki K, Itoh H, Swanson P, Naito N, Nagahama Y, Nozaki M, Nakai Y \& Itoh S 1989 The duality of teleost gonadotropins. Fish Physiology and Biochemistry 7 29-38.

Li SA, Klicka JK \& Li JJ 1986 Effect of androgen and estrogen treatment on hamster liver and kidney estrogen 2-/4-hydroxylase activity. Endocrinology 119 1810-1815.

Lowry OH, Rosebrough NJ, Farr AL \& Randall RJ 1951 Protein measurement with the Folin-phenol reagent. Journal of Biological Chemistry 193 265-275.

MacLusky NJ, Barnea ER, Clark CR \& Naftolin F 1983 Catechol estrogens and estrogen receptors. In Catechol Estrogens, pp 151-176. Eds GR Merriam \& MB Lipsett. New York: Raven.

Nagahama Y 1987 Endocrine control of oocyte maturation. In Hormones and Reproduction in Fishes, Amphibians, and Reptiles, 
pp 171-202. Eds DO Norris \& RE Jones. New York: Plenum.

Nagahama Y 1990 Endocrine control of oocyte maturation in teleosts. In Progress in Comparative Endocrinology, pp 385-392. Eds A Epple, CG Scanes \& MH Stetson. New York: Wiley-Liss.

Nagahama Y 1994 Regulation of oocyte maturation in fish. In Fish Physiology, Vol 13 - Molecular Endocrinology of Fish, pp 393-439. Series eds NM Sherwood \& CL Hew, volume eds AP Parrell \& DJ Randall. New York: Academic Press.

Nagahama Y 1997 17a,20ß-dihydroxy-4-pregnen-3-one, a maturation-inducing hormone in fish oocytes: mechanisms of synthesis and action. Steroids 62 190-196.

Numazawa M, Kiyono Y \& Nambara T 1980 A simple radiometric assay for estradiol-2-hydroxylase activity. Analytical Biochemistry 104 290-295.

Paden CM, McEwen BS \& Fishman J 1983 Binding of catecholestrogens to cell membranes. In Catechol Estrogens, pp 189-201. Eds GR Merriam \& MB Lipsett. New York: Raven.

Parvez H \& Parvez S 1973 Microradioisotopic determination of enzymes, catechol-o-methyltrasferase, phenylethanolamine-nmethyltransferase and monoamine oxidase in a single concentration of brain homogenate. Clinica Chimica Acta 40 85-90.

Poth MA, Axelord J \& Hoffman AR 1983 Estrogen-2-hydroxylase: developmental, hormonal and pharmacologic studies using a radioenzymatic method. In Catechol Estrogens, pp 19-30. Eds GR Merriam \& MB Lipsett. New York: Raven Press.

Quail JA \& Jellinck PH 1987 Modulations of catecholestrogen synthesis by rat liver microsomes: effects of treatment with growth hormone or testosterone. Endocrinology 121 987-992.

Querat B, Hardy A \& Leloup-Hatey J 1985 Plasma levels, metabolic clearance rates, and rates of secretion of testosterone and estradiol-17 beta in the silver eel (Anguilla anguilla L.) General and Comparative Endocrinology 59 482-493.

Rao NV \& Haider S 1992 Oocyte maturation in Clarias batrachus: in vitro effect of various steroids, salmon gonadotropin, cyanoketone and epostane. Indian Journal of Experimental Biology 30 1128-1131.

Scott AP \& Canario AVM 1987 Status of oocyte maturation-inducing steroids in teleosts. In Proceedings of Third International Symposium on The Reproductive Physiology of Fish, pp 224-234. Eds DR Idler, LW Crim \& JM Walsh. St John's, Canada: Third Fish Symposium 1987, Marine Sciences Research Laboratory, Memorial University of Newfoundland.
Senthilkumaran B \& Joy KP 1994 Effects of ovariectomy and oestradiol replacement on hypothalamic serotonergic and monoamine oxidase activity in the catfish, Heteropneustes fossilis: a study correlating plasma oestradiol and gonadotrophin levels. Journal of Endocrinology 142 193-203.

Singh S \& Singh TP 1987 Seasonal profiles of sex steroids in blood plasma and ovarian tissue of Clarias batrachus. General and Comparative Endocrinology 65 216-224.

Spicer LJ \& Hammond JM 1989 Regulation of ovarian function by catecholestrogens: current concepts. Journal of Steroid Biochemistry 33 489-501.

Spicer LJ, Walega MA \& Hammond JM 1987 Metabolism of $\left[{ }^{3} \mathrm{H}\right] 2-$ hydroxysteroid by cultured porcine granulosa cells: evidence for the presence of a catechol-o-methyltransferase pathway and a direct stimulatory effect of 2-methoxyestradiol on progesterone production. Biology of Reproduction 36 562-571.

Sundararaj BI \& Goswami SV 1977 Hormonal regulation of in vivo and in vitro oocyte maturation in the catfish Heteropneustes fossilis (Bloch). General and Comparative Endocrinology 32 17-28.

Swanson P \& Dittman A 1997 Pituitary gonadotropins and their receptors in fish. In Advances in Comparative Endocrinology, vol I, pp 841-846. Eds S Kawashima \& S Kikuyama. Bologna, Italy: Monduzzi editore.

Tekpetey FR \& Armstrong DT 1994 Catecholestrogen modulation of steroid production by rat luteal cells: mechanism of action. Molecular and Cellular Endocrinology 101 49-57.

Thomas P 1994 Hormonal control of final oocyte maturation in sciaenid fishes. In Perspectives in Comparative Endocrinology, pp 619-625. Eds KG Davey, RE Peter \& SS Tobe. Ottawa: National Research Council of Canada.

Upadhyaya N \& Haider S 1986 Germinal vesicle breakdown in oocytes of catfish, Mystus vittatus (Bloch): relative in vitro effectiveness of estradiol-17 $\beta$, androgens, corticosteroids, progesterone and other pregnene derivatives. General and Comparative Endocrinology 63 70-76.

Yoshikuni M \& Nagahama Y 1991 Endocrine regulation of gametogenesis in fish. Bulletin of the Institute of Zoology, Academia Sinica, Monograph 16 139-172.

Received 8 August 2000

Accepted 23 October 2000 